\title{
The role of nurses in transforming health care
}

\author{
Carmen Planas-Campmany ${ }^{\text {** }}$ M Teresa Icart-Isern² \\ From Health Services Research: Evidence-based practice \\ London, UK. 1-3 July 2014
}

\section{Background}

Health care $(\mathrm{HC})$ planning strategies aim to transform $\mathrm{HC}$ models through integrated care schemes and increasing the response capacity of the primary health care (PHC) services. These reforms will require the provision of new roles that are inherently aligned with the nursing model of care [1]. A reflection is needed about the present and future of the Spanish health care system and the role of nurses.

\section{Materials and methods}

The deliberation is based on a textual reading of the Organisation for Economic Co-operation and Development (OECD) statistics of practicing nurses from 2000 to 2011 and the description of the recent situation in the health care area [2].

\section{Findings}

It is widely accepted that nurses play a critical role in providing health care, especially in $\mathrm{PHC}$ and in home care settings. The need for health promotion, preventive interventions and caring for people with chronic conditions suggests that nurses are expected to gain importance. Recent data shows an increased number of nurses per capita in almost all OECD countries. Spain showed one of the largest increases since 2000. However, the number of nurses per capita remained well below the OECD average, with a relatively low number of practicing nurses per practicing physicians (1.39) compared to the 2,8 average ratio in OECD countries [2].

\section{Conclusions}

Governments have to become aware of nurses' contribution. Likewise, nurses have no choice but to position themselves in this new reality, identifying and using their knowledge, their vision of individuals and the ability to provide a genuine perspective based on people's

1Direcció General de Planificació i Recerca en Salut, Barcelona 08028, Spain Full list of author information is available at the end of the article needs. Furthermore, new questions have to emerge regarding nurses and the evolving health policies, regulation, financing and provision and education [3]. For all of these aspects have a direct impact upon nurses and vice versa.

\section{Authors' details}

${ }^{1}$ Direcció General de Planificació i Recerca en Salut, Barcelona 08028, Spain.

${ }^{2}$ School of Nursing. University of Barcelona, Barcelona 08907, Spain.

Published: 7 July 2014

\section{References}

1. Auerbach DI, Staiger DO, Muench U, Buerhaus PI: The nursing workforce in an era of health care reform. N Engl J Med 2013, 368:1470-1472.

2. OECD: "Nurses", in Health at a Glance. OECD Indicators, OECD Publishing; 2011, [Last accessed: April 20th, 2014].

3. Planas-Campmany C, Icart-Isern MT: La aportación enfermera en la rendición de cuentas. Metas Enferm 2013, 16:6-10.

doi:10.1186/1472-6963-14-S2-P59

Cite this article as: Planas-Campmany and Icart-Isern: The role of nurses in transforming health care. BMC Health Services Research 2014 14(Suppl 2):P59.
Submit your next manuscript to BioMed Central and take full advantage of:

- Convenient online submission

- Thorough peer review

- No space constraints or color figure charges

- Immediate publication on acceptance

- Inclusion in PubMed, CAS, Scopus and Google Scholar

- Research which is freely available for redistribution
() Biomed Central
C Biomed Central

(c) 2014 Planas-Campmany and Icart-Isern; licensee BioMed Central Ltd. This is an Open Access article distributed under the terms of the Creative Commons Attribution License (http://creativecommons.org/licenses/by/4.0), which permits unrestricted use, distribution, and reproduction in any medium, provided the original work is properly cited. The Creative Commons Public Domain Dedication waiver (http://creativecommons.org/publicdomain/zero/1.0/) applies to the data made available in this article, unless otherwise stated. 